Binghamton University

The Open Repository @ Binghamton (The ORB)

$1-2014$

\title{
The Performance Puzzle: Understanding the Factors Influencing Alternative Dimensions and Views of Performance
}

Anna A. Amirkhanyan

American University, amirkhan@american.edu

Hyun Joon Kim

Korea University - Korea, joonk@korea.ac.kr

Kristina T. Lambright

Binghamton University--SUNY, klambrig@binghamton.edu

Follow this and additional works at: https://orb.binghamton.edu/public_admin_fac

Part of the Public Administration Commons

\section{Recommended Citation}

Amirkhanyan, Anna A.; Kim, Hyun Joon; and Lambright, Kristina T., "The Performance Puzzle: Understanding the Factors Influencing Alternative Dimensions and Views of Performance" (2014). Public Administration Faculty Scholarship. 31.

https://orb.binghamton.edu/public_admin_fac/31

This Article is brought to you for free and open access by the Public Administration at The Open Repository @ Binghamton (The ORB). It has been accepted for inclusion in Public Administration Faculty Scholarship by an authorized administrator of The Open Repository @ Binghamton (The ORB). For more information, please contact ORB@binghamton.edu. 


\title{
THE PERFORMANCE PUZZLE: UNDERSTANDING THE FACTORS INFLUENCING ALTERNATIVE DIMENSIONS AND VIEWS OF PERFORMANCE
}

\author{
Anna A. Amirkhanyan ${ }^{1}$ \\ Associate Professor \\ Department of Public Administration and Policy \\ School of Public Affairs, American University \\ 4400 Massachusetts Ave, NW \\ Washington, DC 20016 \\ Email: amirkhan@american.edu \\ Phone: 202-885-6289 \\ Hyun Joon $\mathrm{Kim}^{2}$ \\ Associate Professor \\ Department of Public Administration \\ Korea University \\ 145, Anam-ro, Seongbuk-gu \\ Seoul 136-701, Korea \\ Email: joonk@korea.ac.kr \\ Phone: 82-2-3290-2289 \\ Kristina T. Lambright \\ Associate Professor \\ Department of Public Administration \\ College of Community and Public Affairs \\ P.O. Box 6000 \\ Binghamton University \\ Binghamton, New York 13902 \\ Email: klambrig@binghamton.edu \\ Phone: 607-777-9186
}

\footnotetext{
${ }^{1}$ This paper is an equal collaboration; the order of authorship is alphabetical.

${ }^{2}$ Please address correspondence to Hyun Joon Kim at joonk@korea.ac.kr.
} 


\section{Acknowledgement}

We are grateful to three anonymous reviewers and the JPART editor for their helpful comments.

\section{Funding}

This work was supported by a faculty research grant from the College of Political Science and Economics at Korea University. 


\title{
THE PERFORMANCE PUZZLE: UNDERSTANDING THE FACTORS INFLUENCING ALTERNATIVE DIMENSIONS AND VIEWS OF PERFORMANCE
}

\author{
Abstract: There is a large literature on the determinants of organizational performance, \\ and its multi-dimensional nature is well-recognized. However, little research examines how \\ different organizational and environmental factors influence different stakeholders' performance \\ assessments of the same service. We address this gap by comparing the factors influencing \\ performance evaluations by different constituencies of child care centers in Ohio. We \\ operationalize performance using: (1) regulatory violations documented during state licensing \\ inspections, (2) satisfaction with the center's quality reported by center directors, (3) satisfaction \\ with the center's quality reported by teachers, and (4) satisfaction with care quality reported by \\ parents. Our findings suggest that different organizational and environmental factors are \\ associated with the performance assessments of different constituencies. In addition, some of \\ these constituency assessments appear to influence each other.
}




\section{INTRODUCTION}

Organizational performance has been a key concern for public administration scholars (Amirkhanyan, Kim, and Lambright 2008; Boyne 2003; Boyne, Meier, O’Toole, and Walker 2005; Brewer and Selden 2000; Meier, O’Toole, Boyne, and Walker 2007; Moynihan and Pandey 2005; Rainey and Steinbauer 1999; Selden and Sowa 2004). It is broadly accepted that performance is a complex phenomenon with a range of different dimensions viewed from the perspectives of diverse stakeholders (Andrews, Boyne, and Walker 2006; Boyne et al. 2005; Boschken, 1992, 1994; Brewer and Coleman 2000; Cameron, 1978, 1981, 1982; Kaplan and Norton 1992; Quinn and Rohrbaugh 1981, 1983; Rojas 2000; Selden and Sowa 2004). In public management research, these dimensions have been translated into numerous alternative measures (Amirkhanyan et al. 2008; Andrews et al. 2006; Selden and Sowa 2004; Walker and Boyne 2006), and there is a large literature on the determinants of performance (Boyne 2003; Brewer 2006; Brewer and Selden 2000; Moynihan and Pandey 2005; Rainey and Steinbauer 1999). However, little research examines whether different organizational and environmental factors influence different stakeholders’ performance assessments of the same service.

This article improves our understanding of the complex nature of organizational performance by investigating the relationship between a set of organizational and environmental characteristics and numerous service outcomes evaluated by different constituencies. Focusing on nonprofit and for-profit child care centers operating under Head Start contracts in Ohio, we operationalize performance using: (1) regulatory violations documented during state licensing inspections, (2) satisfaction with the overall quality of the center reported by the center directors, (3) teachers' satisfaction with the overall quality of the center, and (4) parents' satisfaction with the overall quality of the child care. We explore a range of factors that may be related to each of 
the four performance assessments provided by the following key constituencies: regulators, senior managers, line staff, and clients.

We begin by exploring various conceptualizations of organizational performance and discussing organizational constituencies and what this implies for performance measurement. Specifically, we detail past research suggesting that different constituencies assess performance differently and that the factors influencing different constituencies’ assessments of various organizational characteristics differ as well. We also draw on the public management literature to identify the ways in which various factors might affect different constituencies’ performance assessments in this study. Next, we use multivariate regression analysis to examine the influence of environmental and organizational factors on performance. We conclude by discussing the implications of our findings.

\section{LITERATURE REVIEW}

Conceptualizations of Organizational Performance. Scholars have conceptualized organizational performance in many different ways. The Goal Attainment Model of organizational performance defines effectiveness as the extent to which an organization achieves its goals (Etzioni 1964; Miles 1981; Price 1972). Several scholars have challenged this model, pointing out that organizations often pursue a range of different (and sometimes conflicting) goals (Boschken 1992, 1994; Campbell 1977; Poister 2003; Rainey 1997). Quinn and Rohrbaugh (1983) propose a model of performance, the Competing Values Framework, which combines the Goal Attainment Model with performance theories stressing internal organizational health (Bennis 1966; Likert 1967) and ability to exploit external resources and opportunities (Yuchtman and Seashore 1967). Quinn and Rohrbaugh argue that effective organizations balance and manage four alternative performance models and that organizations shift their 
emphasis among these models as they move through various life cycle stages. Finally, Connolly, Conlon, and Deutsch’s Multiple-Constituency Model (1980) argues that whether or not an organization is doing a good job is contingent upon who is answering the question rather than on objectively verifiable or "internal” aspects of performance. Organizational constituencies have diverse needs, and none of their perspectives are more "correct" than others.

Reflecting this conceptual pluralism, public management research has identified many ways to measure performance (Boyne et al. 2005; Hatry 2006; Poister 2003). The assessments of performance can vary on a continuum from more objective to more subjective. Objective (or objectively verifiable) are traditionally viewed as the "gold standard" of public management (Andrews et al. 2006). However, objective measures have their weaknesses and sometimes fail to fully capture different dimensions of performance (Andrews et al. 2006; Boyne 2002). They reflect the judgments of powerful groups about what data should be collected (Andrews et al. 2006; Walker and Boyne 2006). Hence, some scholars argue that organizational performance is socially constructed and that all measures are ultimately subjective (Brewer 2006; Brewer and Selden 2000). Objective measures are also frequently selected based upon availability and ease of measurement (Andrews et al. 2006, Chun and Rainey 2005). In short, both political preferences and technical limitations can undermine the validity of objective measures.

Subjective measures of performance represent stakeholders’ perceptions of various aspects of organizational activities (Andrews et al. 2006; Brewer 2006; Brewer and Selden 2000; Selden and Sowa 2004; Moynihan and Pandey 2005; Walker and Boyne 2006). Such measures represent a balance of outputs and outcomes and can offer a more global view of organizational well-being (Moynihan and Pandey 2006). On the other hand, subjective measures often suffer from common-method bias caused by the tendency of respondents to give similar responses to 
distinctive survey questions (Andrews et al. 2006; Brewer 2006; Brewer and Selden 2000; Walker and Boyne 2006). Another weakness is that subjective measures rely on recall and respondents may lack a comprehensive understanding of organizational issues (Golden 1992).

Aside from the subjective-objective dichotomy, performance measures have been differentiated using several other criteria. Measures may be based on the judgments of internal or external stakeholders (Walker and Boyne 2006). They can reflect organizational inputs, outputs and/or outcomes (Cohen and Eimicke 2008; Linder 2004). Finally, performance data can be quantitative and/or qualitative (Blasi 2002). Although theoretically these diverse approaches to measurement provide a more complete picture of organizational performance, different measures may not be complementary empirically, for instance, due to important differences in performance data, reflecting certain managerial tradeoffs.

Dimensions and Views of Performance. In addition to detailing various approaches to measurement, the literature identifies different dimensions of performance (such as costs, quality, equitable access, and regulatory compliance) and different constituency views of performance (such as the perspectives of clients, managers, and regulators). The distinction between dimensions and views of performance is theoretically important here since we incorporate both concepts into this research. Some past studies focus on different dimensions of performance, suggesting that evaluation of public agencies may vary depending on what dimension is used. For instance, Amirkhanyan et al. (2008) examine 17,000 skilled nursing facilities and determine that assessments of nursing home performance diverge based on whether service quality or access to the poor is examined. Levy (2001) and Cameron (1978) also find that organizations can perform well in terms of some dimensions of performance but poorly in others. 
Other studies emphasize a variety of external and internal constituencies that public and nonprofit organizations serve and focus on their views of organizational performance.

Constituency values, training, motivation, political ideology, interests and cognitive abilities shape constituencies' use of performance information (Moynihan 2006), and their views of performance vary accordingly. ${ }^{3}$ For instance, Tsui (1990) finds significant differences in how executives, managers, and employees rated the effectiveness of human resource subunits: the ratings of executives were the highest while the ratings of the employees were the lowest. As another example, Provan and Milward (1995) collected data from a variety of stakeholders to evaluate the effectiveness of mental health networks and find that the assessments of different stakeholders vary. Addicott and Ferlie (2006) and Kelly and Swindell (2002) also find similar results. Taken together, these findings suggest that organizations may be forced to make tradeoffs between priorities valued by different constituencies when trying to meet their performance goals (Boschken 1992, 1994).

This study focuses on three dimensions of performance, reported from four perspectives. The first dimension - regulatory violations - reflects centers’ compliance with regulations evaluated by government inspectors. The second dimension is the overall quality of the child care center, evaluated by two constituencies - center directors and teachers. Assessments of this dimension are likely to reflect broader center-level phenomena such as organizational culture and work environment, physical conditions, operations, the achievement of strategic priorities and client outcomes. Finally, the third dimension of performance, the overall quality of child care, is

\footnotetext{
${ }^{3}$ There is also some empirical evidence suggesting that different constituents assess organizational characteristics other than performance differently, too. Enticott, Boyne, and Walker (2009) report that there are significant differences in how three organizational echelons in English local government authorities assess organizational structure, culture, strategy formulation, and strategy content. Like Tsui (1990), these researchers find that senior staff are more likely to provide positive assessments of their organization than lower-level staff. Phillips (1981) also finds that variation in informant position explains a significant portion of the variation in informant assessments of several different organizational characteristics.
} 
assessed by the parents. While assessing care, parents are likely to focus on the care their child receives and its impact on their child's development. Care quality, evaluated by the parents, is just one aspect of the overall center quality, evaluated by the teachers and the center directors.

Factors Influencing Constituencies’ Assessments. The literature on different constituencies' views of organizational performance provides limited empirical evidence on how different factors influence their assessments. In Tsui's study (1990), the set of environmental context variables had the greatest impact on executives' effectiveness ratings, while the set of adaptive response variables had the greatest impact on the employees’ ratings. Both environmental and adaptive variables influence the managers' assessments. While Tsui's focus is similar to ours, its generalizability to a public setting may be limited because two of the three organizations in Tsui's study were for-profit. Performance measurement is more complicated in public and nonprofit organizations because they do not emphasize a single dimension of performance and lack an equivalent to the private sector’s “bottom line” (Andrews et al. 2006). In addition, public and nonprofit organizations often provide complex services with intangible outcomes that are hard to quantify and measure. Finally, public and nonprofit organizations also tend to experience more political pressures and transparency demands from various external constituencies.

While no other past research compares the factors affecting general performance assessments by different constituencies in public and nonprofit organizations, some studies examine this issue in regards to other organizational characteristics. Walker and Brewer (2008) find that the factors influencing perceptions of red tape vary significantly across different echelons within English local authorities. Walker and Enticott (2004) also find a significant variation in the factors influencing managerial reform values and actions at different government 
echelons. Building upon this research, our study compares the factors influencing performance assessments by different constituencies in a child care setting. Our next section sets the stage by examining the policy context under consideration. The following section then proposes a model of organizational performance based on the existing theoretical and empirical literature.

\section{HEAD START CONTRACTS IN OHIO}

Our study focuses on the performance of community child care centers that receive Head Start funding. The Head Start program was initiated in 1965. Implemented in all fifty states, it helps fund comprehensive child development programming to preschool children of low-income families. The national Head Start program is administered by local Head Start agencies (often structured as community action agencies). In Ohio, local Head Start agencies receive grants from their Region 5 multi-state Head Start office and can form contracts with for-profit and nonprofit child care centers. The purpose of these partnerships is to replace the part-day, part year schedule traditionally offered by Head Start with a full-day, full-year child care option. Child care in these centers is considered "Head-Start-enhanced" through the financial and inkind assistance from the Head Start agencies. The Ohio State Department of Job and Family Services (ODJFS) monitors private child care providers, including the contracted child care centers examined in our study. Data from the ODJFS inspections is one of the performance measures we use.

\section{DETERMINANTS OF ORGANIZATIONAL PERFORMANCE}

This section explores the relationships between a number of independent variables and four measures of organizational performance. While the theoretical literature on performance determinants mostly focuses on a more general conceptualization of organizational performance, our hypotheses focus on how the determinants are related to each of our four measures of 
performance: (1) regulatory violations documented during state licensing inspections, (2) satisfaction with the overall quality of the center reported by the center directors, (3) teachers' satisfaction with the overall quality of the center, and (4) parents' satisfaction with the overall quality of the child care. Our independent variables are categorized into four groups: organizational capacity, organizational traits, the contract relationship, ${ }^{4}$ and control variables. Organizational capacity is an important determinant of performance (Forbes and Lynn 2005; Goerdel 2006; Hou, Moynihan, and Ingraham 2003; Moynihan and Pandey 2005). Adopting Moynihan and Ingraham's perspective (2003), this study considers its numerous dimensions, including internal management capacity. In the literature, internal management capacity has been approached as a broad term ${ }^{5}$ encompassing activities such as identifying goals and strategies, creating and implementing financial, IT, and HR management systems (including systems related to staff motivation and feedback), planning or restructuring organizational activities, managing performance, resolving internal conflicts, and buffering the external environment (Boyne 2003; Boyne et al. 2005; Donahue, Selden, and Ingraham 2000; O’Toole and Meier 1999). The general organizational performance literature finds a positive association between good management practices and organizational performance (Boyne 2003; Brewer and Selden 2000; Donahue et al. 2000; Hou et al. 2003; Meier and O’Toole 2002; Moynihan and Pandey 2005). A review of these and other studies suggests that the overall impact of management ranges from $8 \%$ to $10 \%$ of outcomes in stable programs (Boyne et al. 2005). Although many studies suggest that sound management improves performance, some studies suggest that the impact that different measures of management capacity have on organizational

\footnotetext{
${ }^{4}$ The third group of variables, contract relationship design, is specific to the contracting context of this paper. ${ }^{5}$ Meier and O'Toole, who use a related term "management quality," note that "a measure of managerial quality should be general; it should be related to a wide variety of organizational outputs" (Meier and O'Toole, 2002, p. 640).
} 
outcomes varies. For example, Pitts (2005) finds little evidence of management diversity affecting student outcomes, while management representation improves test results and dropout rates; notably, the effect sizes were somewhat different for each. Similarly, Selden and Sowa (2004) find that IT systems and staff's perception of management infrastructure had a negative effect on children's school readiness, while management's investment in mission, staff training and feedback had a positive impact.

How would the child care administrators' utilization of sound management practices monitoring teaching quality, providing teachers with regular feedback and evaluating programs affect our four outcomes of interest? First, we expect to observe a negative effect on the number of violations: capable managers will be more likely to invest their time and effort in explaining the regulations to staff and keeping them motivated and accountable for their compliance. In terms of the managers' assessments of quality, we hypothesize that capable managers will be more skilled at identifying performance problems and making timely improvements and hence will be more satisfied with their center's performance. Good managers also clearly articulate organizational goals, seek feedback, and empower staff by providing the resources and structures to help improve performance. As a result, higher management capacity is likely to improve teachers' satisfaction with the overall center quality. Finally, more capable managers prioritize customer satisfaction and focus on the aspects of services important to their clients. Hence, we expect to find a positive effect on parental assessments as well.

Financial resources are another aspect of organizational capacity expected to improve performance although scholars recognize that available resources have to be efficiently managed in order for them to positively impact service outcomes (Boyne 2003). While there is a broad consensus predicting a positive association between financial resources and performance, there is 
actually only a moderate amount of evidence supporting this claim; most empirical studies, including those focusing on the effect of per pupil spending, find financial resources do not have a significant effect on performance (Boyne 2003).

Consistent with past theoretical predictions, we hypothesize that resource rich organizations will have more administrative staff and technical capabilities to oversee regulatory compliance with physical environment, safety, staff qualifications, and instruction standards. Thus, financial resources may help reduce the number of regulatory violations. Additional finances also provide managers with more flexibility in addressing environmental or operational challenges and more freedom to explore innovative instructional practices, make capital improvements, and acquire cutting edge resources. These factors may positively affect managers' perceptions of center quality. Additional financial resources may also translate into a better physical environment, greater access to teaching tools, and more generous compensation for teachers. These resources are likely to improve teachers' satisfaction. Finally, financial resources properly invested into center structures and processes should improve the quality of care a center provides, positively impacting parental satisfaction.

Human resources, or what Boyne (2003) refers to as "real resources,” are also considered to be a key predictor of program outcomes and are typically hypothesized to improve performance. Contrary to expectations, the general literature on organizational performance mostly finds that real resources, commonly measured as staff quantity and quality, have an insignificant effect on service quality, customer satisfaction, efficiency and other program outcomes (Boyne 2003). However, within the literature specific to child care outcomes, there is limited empirical evidence suggesting that increased real resources are positively associated with performance: Selden and Sowa (2004) report that staff training expenditures are positively 
related to child care program outcomes. In our study, we include three measures of real resources: the percentage of teachers with a B.A., the percentage of teachers with an M.A. and the student-to-teacher ratio. We expect that working in a center with a larger number of welltrained teachers may reduce teacher burnout, therefore resulting in teacher satisfaction with center quality. Another advantage of these centers is that teachers will have more time and the educational background to aid management in program implementation, thus improving the managers' satisfaction. These centers also may have more satisfied parents. Lower student-toteacher ratios and the presence of better trained teachers provide greater opportunities for students to receive individualized attention, supervision and care, all likely to translate into better parental assessments. Unlike the other three performance measures, we expect real resources to have a mixed impact on violations. Regulators closely monitor child care center staffing levels, and centers with lower student-to-teacher ratios are more likely to be in compliance with these regulations. On the other hand, regulators focus on basic health and safety regulations and are not concerned with whether teachers have advanced degrees. As a result, we do not expect there to be an association between teachers' education and the number of regulatory violations.

In addition, we investigate the impact of several organizational traits: size, ownership, affiliation with an umbrella organization, and client characteristics. The literature provides little consistent evidence on how organizational size impacts performance (Boyne 2003). While larger contractors may benefit from economies of scale, red tape prevalent in larger organizations can negatively impact performance by hampering innovation (Moynihan and Pandey 2005). Also, smaller organizations may be more likely to create a nurturing and intimate environment (Amirkhanyan et al. 2008). Reflecting this mixed evidence, we hypothesize that impact of size on different constituencies' assessments of performance will vary. Large centers will be more 
likely to use standardized procedures which may help reduce violations. On the other hand, teachers and parents may be more satisfied with smaller centers because these centers will be less bureaucratic. Children in smaller centers may be more likely to receive services tailored to their unique needs, and teachers may be able to focus on providing quality care rather than complying with cumbersome procedures. With respect to the last performance measure directors' satisfaction - there are both challenges and advantages associated with managing large and small centers, so we expect to find no association between size and managers' satisfaction.

We also explore the impact of ownership status and specifically examine whether nonprofit centers perform better than their for-profit counterparts. Shareholders of for-profit organizations financially benefit whenever costs are reduced, including when these savings result in poorer service quality (Eggleston and Zeckhauser 2002; Hart, Shleifer, and Vishny 1997). In contrast, nonprofits cannot reward their shareholders but must invest any profits into activities that will advance their mission (Cohen 2001). Consequently, there is less incentive for nonprofits to cut costs by reducing service quality (Amirkhanyan 2010). Nonprofits may also be more mission-driven which may increase staff motivation and result in improved performance (Rainey and Steinbauer 1999). Like Amirkhanyan et al. (2008), we believe that nonprofit status will generally have a positive association with performance. However, we expect that nonprofit ownership will impact the performance assessments of some constituencies more than others. For example, the emphasis nonprofits place on their missions may result in these organizations having better working environments for their employees and being more focused on delivering high quality care and meeting client needs. As a result, both teachers and parents affiliated with nonprofit child care centers may be more satisfied. On the other hand, we do not expect nonprofit status to impact the number of regulatory violations. Regulators are focused on basic 
health and safety regulations and are not concerned about ownership status. We also predict that there will be no association between nonprofit status and managers' satisfaction because managing a nonprofit child care center in comparison to a for-profit one has both advantages and disadvantages depending on a number of other environmental and organizational factors.

In addition, we investigate whether the faith-based status of nonprofit organizations influences performance. Faith-based organizations may not perform as well as their secular counterparts if their ability to hire qualified staff is hampered by certain mission-related constraints (Ebaugh, Pipes, Chafetz, and Daniels 2003) or if dependence on volunteers negatively impacts staff turnover, professionalism and expertise (Amirkhanyan, Kim, and Lambright 2009). Based on these arguments, we hypothesize that the staffing quality and stability at faith-based child care centers may be inferior to those in the secular centers, reducing managers', teachers' and parents' satisfaction. In contrast, we hypothesize there will be no association between faith-based status and the number of violations. Similar to our argument regarding nonprofit status, regulators are focused on basic health and safety within organizations and are not concerned with their religious affiliation.

Another organizational trait scholars who study organizational performance have focused on is network participation (Boyne 2003). As an example of an important network link, this study examines the impact of affiliation with an umbrella organization. Organizations with umbrella-affiliates may perform better compared to their freestanding counterparts because of the benefits they receive from standardization and economies of scale (Amirkhanyan et al. 2008). At the same time, it is possible that these organizations will perform more poorly because managers lack the flexibility to implement strategies designed to improve performance (Amirkhanyan et al. 2008). Consistent with this perspective, empirical research on nursing 
homes suggests that chain affiliation and service quality have a negative association (Harrington, Woolhandler, Mullan, Carrillo, and Himmelstein 2001; O'Neill, Harrington, Kitchener, and Saliba 2003). Mirroring the mixed literature on this topic, our hypotheses on the impact of affiliation vary by constituency. Centers affiliated with umbrella organizations will be more likely to use standardized procedures that help reduce regulatory violations. At the same time, affiliation with a larger organization may be associated with less managerial discretion (Rainey and Steinbauer 1999). In such settings, managers may feel constrained in terms of their ability to make strategic changes and to define the center's direction, which would decrease their satisfaction. Teachers may also be less satisfied working for centers affiliated with larger organizations if they have less flexibility to design their curriculum and shape their classroom environment. Finally, increased standardization at the umbrella-affiliated centers may result in children receiving less individualized attention, reducing parental satisfaction.

Like many other performance studies (Amirkhanyan et al. 2008; Goerdel 2006; Meier and O'Toole 2002, 2003; Selden and Sowa 2004), we examine client characteristics. We consider the percentage of white students and the percentage of subsidized students at a center. These two variables are intended to measure the percentage of children from vulnerable backgrounds attending a center, reflecting the fact that poverty and racial inequities often create service delivery challenges in educational settings (Jencks and Phillips 1998). We hypothesize a negative association between the percentage of vulnerable clients a center serves and all four performance measures. Centers serving a higher percentage of vulnerable clients will be under greater financial stress because the fees that the center is able to charge will be lower, and parents will be less likely to pay their bills. Directors at these centers will spend more time trying to improve the financial solvency of the center and less time on services. These pressures 
may decrease their satisfaction with the care their centers provide. It may also be more difficult for the teachers to do their jobs effectively if a high percentage of students are from vulnerable backgrounds. Teachers may have to spend more time assisting the students struggling with education and behavioral issues. Consequently, outcomes for all students at the center regardless of their background may be worse, negatively impacting performance assessments made by directors, teachers and parents. The challenges created by having vulnerable clients may also distract staff attention from regulatory compliance, ultimately resulting in more violations. Finally, parents may have a negative image of centers serving a high percentage of disadvantaged clients regardless of the true quality of care provided.

The community child care centers in our study have contracts with local Head Start agencies, and hence the contracting relationship a center has with Head Start may impact its performance. One aspect of the contract relationship often considered in the literature is the degree of trust and cooperation between the two parties (Artz and Brush 2000; Macneil, 1974, 1978, 1983; Sclar 2000). In this study, we explore the effect of relationship strength on performance. In the instances of a strong contracting relationship, the local Head Start program and child care center will have open communication channels, agree on key goals and processes, and base their actions on trust and cooperation. This may lessen a contractor's opportunistic behavior and reduce the need for monitoring. If the local Head Start program chooses to reinvest these savings into the service delivery system, contractor performance may be further improved.

We hypothesize that strong contracting relationships will have a direct and positive effect on directors’ assessments of quality. Center directors are most likely to be responsible for managing Head Start contracts and are likely to be more knowledgeable than other staff about the nature of the contracting relationship as well as the relationship's strengths and weaknesses. 
Directors involved in partnerships that have a shared understanding of Head Start goals, participatory procedures, and cooperative program implementation will have a clearer understanding of the Head Start agency's expectations and will see these expectations as more meaningful. They will also be better able to tailor their service delivery system to meet Head Start goals. On the other hand, the strength of contracting relationships should not have a direct impact on teacher and parent assessments of care because these constituencies' awareness of contract-related matters is more limited. Similarly, we do not expect the strength of the contracting relationship to influence centers' regulatory compliance because the ODJFS, not the local Head Start agency, is responsible for monitoring adherence to state child care regulations.

Another aspect of contracting influencing contractor performance is completeness - the extent to which the terms of agreement are formally specified. Here, competing hypotheses can be proposed. On the one hand, completeness can contribute to goal clarity and agreement, minimize conflict and positively affect constituency satisfaction. It may also make it easier for the principal to hold an agent accountable (Romzek and Johnston 2005). At the same time, as formalization increases, more resources may need to be devoted to contract specification, negotiation and monitoring (Amirkhanyan, Kim, and Lambright 2010; Boukaert and Peters 2002). From the agent's perspective, staff will have to devote more time to the administrative tasks and fewer resources may be available for core programmatic activities, negatively affecting performance (Amirkhanyan et al. 2010).

While both hypotheses are plausible when predicting contractor performance in general situations, we believe only the latter hypothesis is applicable in this study given its specific policy context and measures: we predict that there will be a negative association between contract completeness and directors' and teachers' satisfaction. By including relationship 
strength in our model as another independent variable, we are already assessing whether the local Head Start program and child care center have shared expectations. Therefore, contract completeness in this context measures whether having shared expectations recorded in official documents rather than shared expectations communicated through informal channels influences performance. Child care providers (a) deliver a "soft" service with outcomes that are relatively difficult to measure, (b) serve vulnerable clients (who are unable to monitor and report problems), and (c) have professional values that are not likely to be fully shared by public funders. These considerations contribute to the contractors' need for flexibility and use of professional judgment. This setting is consistent with DeHoog's (1990) description of collaborative contracts where the two sides understand they cannot record all possible contingencies and must have an open mind and willingness to work together as new problems arise. In such settings, official documentation outlining the processes and the outcomes is likely to generate conflict. For these reasons, we hypothesize that increasing contract completeness will negatively affect directors' and teachers’ assessments of center quality. We also expect that contract completeness will not affect parent satisfaction or regulatory violations. Both the parents and the ODJFS - the public agency responsible for monitoring adherence to state regulations - are unlikely to have much knowledge of the contracts between Head Start and local child care centers.

As a final aspect of the contract relationship, we examine relationship length, measured as the length of time the child care center has had a contract with their local Head Start agency. Again, this association is complex, and the impact that relationship length has on different constituencies’ assessments may vary. On the one hand, principles and agents are likely to develop shared goals in longer relationships which could positively impact agents’ performance (Amirkhanyan et al. 2010). Managers working for centers with longer ties to Head Start may 
better understand Head Start's goals and tailor their services to those goals, increasing director satisfaction with center quality. On the other hand, principals may become complacent about monitoring long-term contracts (DeHoog 1990), which may result in declined contractor performance. Complacent managers may fail to communicate regularly with Head Start representatives, which would compromise their ability to meet contract expectations and negatively impact managers' assessments. Hence, the impact of relationship length on directors' assessments is unclear. Teachers, parents and regulators, unlike center directors, are likely to have little or no involvement with the contracting process. Therefore, we argue that relationship length will not influence performance assessments made by these constituents. The only effects on teacher or parent satisfaction would likely be realized indirectly through internal operations.

In summary, our model outlines a set of key factors hypothesized to affect performance. Table 1 details our theoretical predictions. Note that regulatory violations are a negative measure of performance. We expect the impact that several predictors will have on performance assessments will vary by constituency.

$<$ Table 1 about here. $>$

\section{METHODS}

Data. Our data come from the Partnership Impact Research Project (PIRP), a threeyear survey of education partnerships in Ohio. ${ }^{6}$ In this article, we used four PIRP data sets:

1. The Child Care Center Data Set contains information on nonprofit and for-profit child care centers. The data is provided by the center directors and focuses on the population served, services, funding sources, and other major characteristics of

\footnotetext{
${ }^{6}$ The formal title of the data set is ICPSR04298-v1, 2001-2004 available at http://dx.doi.org/10.3886/ICPSR04298.v1. From 2001 to 2004, the Education Development Center conducted a three year study to evaluate the partnerships among Head Start agencies and private child care centers and assess child care quality and access to child care services in Ohio.
} 
contractors. The original data was constructed by stratifying licensed child care centers in Ohio. The study team first divided the centers into two groups: centers partnering with Head Start, and those who are not. Then, centers were further stratified by urbanicity. From the stratified sample, 221 eligible child care centers were randomly selected, and 141 of them agreed to participate in this survey. In the first round data set, 78 child care centers have a partnership with a local Head Start agency in Ohio while 63 centers do not. The number of respondents varies by round because of changes in partnership status and centers dropping out of the study.

2. The Child Care Center Partnership Data Set contains information on the child care centers' contracts with a local Head Start agency in Ohio and focuses on various aspects of these contractual relationships. This partnership-level data set pertains to a sub-sample of centers included in the Child Care Center Data Set mentioned above.

3. The Parent Data Set includes information collected from a self-selected sample of parents on services their children have received and satisfaction with service quality. This is parent level data, and thus it includes responses of several parents whose children attended the centers included in the Child Care Center Data Set. Across the three rounds of data collection, 1,691 parents completed parent surveys. The respondents come from a wide range of geographical areas in Ohio. Roughly $33 \%$ of respondents sent their children to urban centers, $42 \%$ were using suburban centers, and $25 \%$ were from small towns or rural areas.

4. The Teacher Data Set includes information collected from the teachers working in each center and focuses on their evaluation of the processes and experiences they encounter at their workplace. This is teacher level data which includes responses of several teachers in each center from the Child Care Center Data Set. Across the three rounds of data collection, 408 self-selected teachers completed teacher surveys. The teacher data also represent various locations in the state: $36 \%$ of the respondents worked at urban centers, $41 \%$ were from suburban centers, and $23 \%$ were from centers in small towns or rural areas.

Each data set includes pooled time-series data with up to three records for each organization (or each partnership). First, we merged the first two data files by center IDs and wave indicators.

The centers with no Head Start contract were eliminated. Since the parent and teacher data contained individual level data, we computed center-level aggregate measures for all variables used from these data sets (by separately averaging the values of each variable at the center level) and merged the teacher and parent data with the first two data files. Using the combined data set, we tested the proposed models with OLS and ordered logit. Appendix 1 describes our measures. 
Dependent Variables. We use four measures of performance provided by different constituencies: state government inspectors, center leadership, teachers and parents. Our first measure is an interval-ratio variable measuring the "number of violations documented during the state licensing inspection.” The ODJFS formally licenses private child care centers in Ohio and conducts regular inspections of these facilities. The ODJFS's child care regulations establish minimum health, program and safety standards and cover license/approvals, staffing requirements, grouping, space requirements, program equipment, policies/procedures, safety/discipline, health, children's records, nutrition, handwashing/diapers, and infant care. The violations are assigned by state regulators and in our data the assigned values range from 0 to 49 with a large share of cases clustered around lower values.

The three remaining dependent variables are subjective assessments of a child care center's performance. The first subjective measure is based on directors' responses to the question: "How satisfied are you with the overall quality of your center?" (response categories include: "very satisfied” (5), "somewhat satisfied” (4), "neither satisfied nor dissatisfied” (3), "not very satisfied” (2), and "not satisfied at all” (1). In the survey, each center director first provided some background information on their center, such as teacher training and professional development, parental involvement, center services, and center administration and organization. The question on satisfaction with the center quality was strategically placed after these issues had been discussed, and hence the answers can be expected to be informed by these complex considerations. The second subjective measure is the teachers' evaluation of overall center quality. While the individual responses are at the ordinal level, an aggregate measure (centerlevel average) was created to reflect the average assessment of each center by all teachers surveyed within a particular center. Our third subjective measure is based on parents' evaluation 
of service quality. A center-level mean score of parents' responses was created for each child care center and used as a dependent variable in this analysis.

While our four dependent variables incorporate diverse viewpoints, they do not directly measure the degree to which centers achieve essential goals of child care, such as the behavioral, socialization, and educational growth of children. The measures available to us are limited to assessing regulatory compliance and service quality, intermediate outcomes, rather than the ultimate outcomes child care centers pursue. Future research should examine the impact that independent variables included in this study have broader child care goals. For example, scholars could assess children's readiness for kindergarten as a measure of a child care center's effectiveness.

Independent Variables. The first group of independent variables includes several measures of organizational capacity. Internal management practices is the sum of seven survey items assessing various managerial activities. To capture human resource capacity of a center, we include three measures: the proportion of teachers with a Bachelor's degree, the proportion of teachers with a Master's degree and the student-teacher ratio. The first two human resource capacity variables measure the quality of human resources. The third variable reflects their quantity, which often translates into quality by allowing teachers to provide more individualized attention to each child. The budget per student ratio is used to measure the availability of financial resources within each child care center.

We included some additional measures of organizational characteristics. The total annual operating budget and the average daily enrollment of preschoolers measure organizational size. The two ownership measures are whether the child care center is nonprofit and whether it is a faith-based organization. To measure the child care center's external ties, we 
created a dummy variable indicating whether a center was a part of a larger agency or umbrella organization. Finally, a set of variables reflects client demographics: the percentage of white students and the percentage of subsidized students at each center.

We also incorporated numerous measures reflecting the contracting relationship between Head Start agencies and the centers. We used two measures of relationship strength. Current relationship strength is the mean of four variables: (1) shared procedures which reflect the existence of formal and informal procedures governing the partnership, (2) goal agreement which measures the contractors' perception of both parties' agreement on contract goals, (3) communication quality which assesses the degree to which child care center directors believe they maintain good communication with the local Head Start program, and (4) cooperation in contract implementation which describes a variety of cooperative practices. To assess the reliability of the scales for these four variables, we calculated Cronbach's alphas. The results show acceptable alpha scores ranging from 0.792 to 0.906 . Finally, a composite current relationship strength variable was created by calculating the mean of these four variables. This measure characterizes the design of the contracting relationship at the time of the survey. In addition, we account for the elements of relationship strength exhibited at the contract development and specification stage. Since some aspects of strong relationships may be viewed as “deference” in disguise due to the contractor's power, information on the contractor's input in the specification process may also help separate the effect of the contractor's power. We have created a dummy variable collaborative contract development indicating whether the contract was developed with input from both the local Head Start program and child care center. The variable contract completeness measures the degree of specification in the contract. The last variable focusing on the contract relationship in our model is relationship length. This variable 
is measured as the number of years a child care center has maintained the partnership with a local Head Start agency.

Finally, we use a number of controls in each model. Since the partnerships we focus on were studied over time, we separate the year fixed effects by including two dummies indicating the wave of each survey record in all models. Recognizing the importance of geographical conditions, we use a dummy variable indicating whether the center is in a "small town" or "rural area” (as opposed to an "urban” or "suburban” area). The teachers' model also includes the following set of controls describing that constituency: benefits centers offer to teachers, administrative support for teachers, and training opportunities for teachers. These measures are the center-level mean scores of responses to questions on these respective topics. Lastly, the parents' model controls for parents' age, parents' participation in the classroom, intensity of center use, Head Start client status, parents' contribution to education at home, parents' education level, and parents' race. Like the controls in the teachers' model, the control variables in the parents' model are computed by averaging the responses at each center.

Analysis. We ran four regression models: (1) the violations model where the dependent variable is the number of regulatory violations for each child care center; (2) the directors' model where the dependent variable is child care center directors' satisfaction with center quality; (3) the teachers' model where the dependent variable is the average center quality rating provided by teachers; and (4) the parents’ model where the dependent variable is the average center quality rating provided by parents. Each model analyzes the relationship between performance and various independent variables. As mentioned above, the teachers' and the parents' models include teacher specific or parent specific independent variables to control for the effects of stakeholder characteristics on performance assessments. We analyzed the violations, teachers' 
and parents' models using OLS regression. We used ordered logit to analyze the child care center directors' satisfaction because this dependent variable is ordinal.

Using survey data for testing a regression model always raises a legitimate concern for common source bias. However, we believe that common source bias is not a significant threat to the validity of our analysis. First and foremost, our data set is composed of data collected from multiple sources. The data for the four dependent variables (i.e. violations, directors' satisfaction, teachers' satisfaction, and parents' satisfaction) were collected from a state agency, center directors, teachers, and parents, respectively. Second, the management capacity variables, except for the internal management practices variable, represent factual information about the management practices in the centers rather than a subjective assessment of management quality. Hence, these are not subjective measures per se. Third, among the four regression models we tested, the directors' satisfaction model is potentially most vulnerable to common source bias because the same directors answered the survey questions related to center quality as well as management capacity and contract relationship design. But again, since many of the measures reported by center directors are either a description of organizational practices or characteristics, the possible effect of common source bias on the findings for this model would be marginal.

Study Limitations. While our study has many strengths, including four different measures of performance and a wide array of independent variables, it also has some limitations. Child care center performance may be a function of a number of factors not included in our study such as market competition (Milward and Provan 2000; Romzek and Johnston 2005), structural differences in organizational configurations (Brewer and Selden 2000; Moynihan and Pandey 2005) and organizational culture and leadership styles (Boyne 2003; Brewer and Selden 2000; Moynihan and Pandey 2005). Measures for these variables were not available from this data set. 
It is difficult to predict precisely how these omitted variables might bias our results particularly because the literature on the effects of these factors on performance is very mixed (e.g., the effect of competition on performance). Future research may seek to create a complementary data set to overcome the concerns of omitted variable bias in this study.

\section{FINDINGS}

Descriptive statistics are presented in Table 2. When comparing the results across the four regression models, we find that the violations model shown in Table 3 has the smallest number of significant variables. The student-teacher ratio, budget-student ratio, and percentage of white students are all positively related to the number of regulatory violations identified by the state inspectors. Note that the dependent variable is a negative measure of performance (i.e. the higher number of violations, the worse the performance). A higher student-teacher ratio - i.e., fewer teachers at the center - is associated with more regulatory violations, which is not counterintuitive. But contrary to expectations, we find that higher budget-student ratios and higher percentages of white students increase the number of violations a center has. Consistent with our prediction, larger annual budgets, a proxy measure of organizational size, are associated with fewer violations. ${ }^{7}$ Of the four significant variables in the model, the effect size of the studentteacher ratio is greatest.

$<$ Table 2 and 3 about here.>

As shown in Table 4, several variables are significant in the directors' model. Centers with a higher proportion of teachers with a Bachelor's degree have more satisfied directors.

\footnotetext{
${ }^{7}$ An anonymous reviewer suggested that we use a fixed effect model to average out time invariant factors. We ran a fixed effects regression by grouping the data by survey wave. The results show that the correlation between the fixed effects and the other independent variables is only 0.099 . The rho is also low at 0.031 . The F-test failed to reject the null hypothesis that all fixed effects are zero with the probability of 0.492 . Hence, fixed effects are not a concern in the violation model. We were not able to conduct a fixed effects analysis for the directors' model because the ordered logit fixed effects model was too complex to estimate. The results of the fixed effects estimation for the teachers' model and the parents' model are similar to the violation model: the presence of fixed effects was not confirmed.
} 
This variable also has the greatest effect size. In addition, the percentage of white students has a positive association with perceived quality. But, the budget per student ratio is negatively associated with directors' satisfaction. Similar to the finding in the violations model, this suggests that greater financial resources per student are correlated with decreased perceived performance. Among the four contract relationship variables, an increase in contract completeness decreases directors' satisfaction. On the other hand, the coefficient of current relationship strength is positive and significant. These two findings suggest that strong relationships between Head Start and the provider rather than contract specification efforts enhance directors' satisfaction. For sensitivity analysis, in order to reduce the "halo effect" associated with directors' propensity to rate their service as satisfactory, we created a dichotomous nominal variable coded as 1 for "very satisfied" and 0 for all other responses and ran a logit analysis. Estimation results were almost the same between these two models except for some differences in the magnitudes of the coefficients. Thus, a halo effect is not a concern in this analysis.

< Table 4 about here.>

Table 5 suggests that a fairly diverse set of independent variables predict teachers' ratings of service quality. First, working at a center with a higher proportion of teachers with a Master's degree improves teachers' assessments. On the other hand, teachers working at a center affiliated with a larger agency or umbrella organization are less likely to be satisfied with their center's quality. In addition, two contract relationship variables are significant which was contrary to our expectations of no impact. Collaboratively developing contracts has a negative effect on teachers' assessments, and relationship length is positively associated with teachers' assessments. Among the three teacher-related control variables, teachers' ratings of employee 
benefits and administrative support provided to teachers have significant positive effects on perceptions of quality (with the latter variable having the largest effect size in the model).

$<$ Table 5 about here. $>$

The broadest set of variables determines parents' quality assessments as shown in the first three columns of Table 6 . Use of sound internal management practices is associated with higher parent ratings of quality. On the other hand, parents whose children are attending childcare centers affiliated with large umbrella organizations expressed lower satisfaction. Parents' assessments are also generally lower in schools with a greater percentage of white students and with a greater percentage of subsidized students. Similar to the previous models, we find that the strength and length of the partnerships between centers and Head Start agencies both significantly improve parent ratings of care quality. Among the seven parental traits, the intensity of child care service used and the percentage of white parents participating in the survey have a positive effect on parents' ratings of performance (with the latter variable having the largest effect size in the model). Lastly, parents give higher quality ratings to centers located in rural areas.

$<$ Table 6 about here.>

Since parents are the end users of the service and their satisfaction, perhaps, more closely describes child care outcomes, we also ran a fifth model as a sensitivity analysis, using parent assessments as the dependent variable and including all the other quality assessments provided by other constituencies as independent variables. ${ }^{8}$ This model examines how regulatory

\footnotetext{
${ }^{8}$ The dependent variables in the other three models are added into the fifth model as independent models. Hence, this sensitivity analysis may have an endogeneity problem: the number of violations, directors' satisfaction, and teachers' satisfaction may be correlated with the errors, and the OLS estimates could be inconsistent and biased (Gujarati, 1995). If that is the case, two stage least squares can be considered as an alternative estimation method (Griffiths, Hill, and Judge, 1993). We ran a Hausman test to figure out which method is preferred as suggested by $\mathrm{Wu}$ (1973). The test result shows that 2SLS is not preferred to OLS. Based on the result, we report the findings from the OLS estimation for the fifth model.
} 
violations as well as managerial and employee assessments correlate with clients' satisfaction. Among the three service quality measures, only teachers' satisfaction is positively and significantly related to parents' assessments of service quality. We also find that as the studentteacher ratio increases, parent satisfaction declines. Findings related to organizational traits are mostly consistent with the parents' model without the endogenous variables except for the insignificant effect of the percentage of subsidized students. None of the four contract relationship variables appear to affect parents' satisfaction with care quality. In addition, intensity of service use and age of parents are positively associated with parents' satisfaction.

\section{DISCUSSION AND CONCLUSION}

This study explores whether performance assessments of different organizational stakeholders are influenced by various organizational and environmental factors. Overall, these results confirm our expectation that different factors matter to different constituencies. Table 7 provides a summary of our findings and the effect sizes of significant variables.

$<$ Table 7 about here. $>$

In Table 7 , the scores of partial eta ${ }^{2}$ indicate the proportion of variability in the dependent variable explained by the corresponding explanatory variable. The results show that some of the teacher-related and parent-related control variables had a greater effect on assessments of center quality than other significant variables in the models with these controls. In the parents' model, parents' race and the intensity of child care service use were two of the three most influential variables determining parents' satisfaction with child care. In the teachers’ model, administrative support for teachers had the greatest effect size with a magnitude of 0.536.

Hausman's Specification Test Results Comparing OLS to 2SLS

\begin{tabular}{|l|l|l|}
\hline DF & Statistic & Pr $>$ ChiSq \\
\hline 36 & 13.33 & 0.999 \\
\hline
\end{tabular}


Although due caution is necessary for interpreting the implications of relative effect sizes, these findings might indicate that teachers and parents determine their satisfaction based upon what they directly experience and observe in the service delivery process. In other words, constituents located at the end of service delivery process pay less attention to what is going on behind the management curtain.

Also as illustrated by Table 7, several contract relationship variables are significant. Current relationship strength is associated with positive assessments of performance by directors and parents. On the other hand, contract completeness has a negative association with director evaluations of center quality. In addition, we find parent and teacher satisfaction increases as contract length increases, and collaborative contract development decreases teacher satisfaction.

The interpretations of the significant contract relationship variables in the directors' model are relatively straightforward. Contracting relationships that involve trust, shared goals and clear communication empower leadership in contracted organizations, thereby improving management's satisfaction with organizational performance. This finding is consistent with the growing literature on relational contracting that suggests strong contracting relationships can have a range of positive effects (Brown et al. 2006; Lambright 2009; Van Slyke 2007). At the same time, director satisfaction with center quality declines as contract specification increases. The need to comply with additional administrative requirements entailed in more detailed contracts may undermine directors' perceptions of their own productivity and ability to focus on the programmatic aspects of service delivery, which in turn lowers their satisfaction.

Our findings that contract relationship variables impact ratings by teachers and parents, who are not directly involved in the partnership between the local Head Start program and child care center, are intriguing. While parents and teachers are not in a position to assess and be 
directly influenced by the dynamics of the contracts, the relationship variables included in our study may impact other factors in child care settings that are more readily observable by the teachers and parents. This, in turn, may influence these constituencies' performance assessments. For instance, open lines of communication between the government and contractor may aid in the speedy resolution of performance problems, resulting in improved parental satisfaction.

We also find that human resources are a significant predictor of several dimensions of performance considered in our models. Our results specifically indicate that lower student-toteacher ratios improve regulatory compliance and that increased teacher training results in more satisfied directors and teachers. The positive relationship between the student-to-teacher ratio and the number of regulatory violations is not surprising since student-to teacher ratios are a common focus for child care regulations. The other finding is more interesting and suggests that it may be easier for teachers who are better educated to work with center leadership.

Another important finding is that nonprofit ownership does not impact performance assessments made by teachers and parents. The literature on cross-sectional assessments of performance in different service areas suggests that nonprofit organizations deliver higher quality services compared to for-profits (Amirkhanyan et al. 2008; Morley 2006). Nonprofits’ reliance on private donations, volunteers, and their tax exempt status as well as the constraints on compensation for organizational officers have been traditionally viewed as effective safeguards against moral hazard and opportunistic behavior (Amirkhanyan 2010). However, our findings pertaining to the field of child care fail to find any significant effect of sector. These nonfindings contribute to the ongoing discussion on whether government agencies should prefer nonprofit service providers as a matter of policy or whether government agencies should apply more stringent regulations to for-profit contractors. 
Among the findings that necessitate follow-up research is the negative impact that the budget per student variable has on the regulatory violations and directors' assessments of quality. These results are interesting in the context of the ongoing debate in the education finance literature on the effect of financial resources on education quality. While some argue that the key issue is not the lack of resources but their effective and efficient use (Hanushek 1996), others conclude that resource availability is an important predictor of student outcomes (Greenwald, Hedges, and Laine 1996). Our study provides evidence that human resources, but not the absolute amount of financial resources per student, affects stakeholders’ assessments of performance. It is important to note that we use cross-sectional data, and hence reverse causality cannot be ruled out: schools with regulatory violations and operational problems may receive additional funding from various sources to help address these problems.

Finally, our findings indicate that the racial composition of the student body has a mixed impact on performance assessments. While centers with a higher percentage of white students have more satisfied directors, they also have higher numbers of regulatory violations and less satisfied parents. The parents whose children attend predominantly white centers may expect higher quality service than those who receive care in more diverse facilities. It is also possible that the parents' demands translate into tougher inspection standards (e.g., due to complaints and demands for higher quality care) and hence more regulatory violations.

Certainly, more research is necessary in this area, but our study suggests that different organizational and environmental factors influence different constituencies’ performance assessments. Consistent with the Multiple Constituency Model (Connolly, Conlon, and Deutsch 1980), we conclude that focusing on a single measure reflecting one specific constituency's assessment of organizational work limits our understanding of organizational success and its 
determinants. Our findings also suggest that performance assessments are not independent: the factors that improve the perceptions of internal stakeholders may indirectly affect the perceptions of external stakeholders who received services from the "street-level" staff. In addition, these findings may explain why program evaluation tools adopted to assess and eventually boost organizational performance often fail. Tools that narrowly define organizational performance by only focusing on its more objective aspects ignore the multi-dimensional nature of performance and may fail to target important factors influencing performance. Thus, among other things, it may be beneficial to widen the scope of government assessments of regulatory compliance in order to gain more insight into the true impact of public and private organizations on their communities.

\section{REFERENCES}

Addicott, R., and E. Ferlie. 2006. A qualitative evaluation of public sector organizations: Assessing organizational performance in health care. In Public service performance: Perspectives on measurement and management, ed. G. A. Boyne, K. J. Meier, L. J. O’Toole, and R. M. Walker. New York: Cambridge University Press.

Amirkhanyan, A. 2010. Monitoring across sectors: Examining the effect of nonprofit and forprofit contractor ownership on performance monitoring in state and local government contracts. Public Administration Review 70:742-55.

Amirkhanyan, A. A., H. J. Kim, and K. T. Lambright. 2008. Does the public sector outperform the nonprofit and for-profit sectors? Evidence from a national panel study on nursing home quality and access. Journal of Policy Analysis and Management 27:326-53. . 2009. Faith-based assumptions about performance: Does church affiliation matter for service quality and access? Nonprofit and Voluntary Sector Quarterly 38:490-521. . 2010. Do relationships matter? Comparing the performance of relational and classic contracts. Public Performance and Management Review 34:189-220.

Andrews, R., G. A. Boyne, and R. M. Walker. 2006. Subjective and objective measures of organizational performance: An empirical exploration. In Public service performance: Perspectives on measurement and management, ed. G. A. Boyne, K. J. Meier, L. J. O’Toole, and R. M. Walker. New York: Cambridge University Press.

Artz, K.W., and T. H. Brush. 2000. Asset specificity, uncertainty and relational norms: An examination of coordinating costs in collaborative strategic alliances. Journal of Economic Behavior and Organization 41:337-62.

Andrews, R., G. A. Boyne, and R. M. Walker, R.M. 2006. Subjective and objective measures of organizational performance: An empirical exploration. In Public service performance: 
Perspectives on measurement and management, ed. G. A. Boyne, K. J. Meier, L. J. O’Toole, and R. M. Walker. New York: Cambridge University Press.

Blasi, G. J. 2002. Government contracting and performance measurement in human services. International Journal of Public Administration 25:519-38.

Boschken, H. L. 1992. Analyzing performance skewness in public agencies: The case of urban transit. Journal of Public Administration Research and Theory 2:265-88.

1994. Organizational performance and multiple constituencies. Public Administration Review 54:308-12.

Bouckaert, G., and B. G., Peters. 2002. Performance measurement and management: The Achille's heel in administrative modernization. Public Performance and Management Review 25:359-62.

Boyne, G. A., K. J., Meier, L. J. O'Toole, and R. M. Walker. 2005. Where next? Research directions on performance in public organizations. Journal of Public Administration Research and Theory 15:633-9.

Boyne, G. A. 2002. Concepts and indicators of local authority performance: An evaluation of the statutory framework in England and Wales. Public Money and Management 22:1724.

2003. Sources of public service improvement: A critical review and research agenda. Journal of Public Administration Research and Theory 13:367-94.

Brewer, G. A. 2006. All measures of performance are subjective: More evidence on US federal agencies. In Public service performance: Perspectives on measurement and management, ed. G. A. Boyne, K. J. Meier, L. J. O’Toole, and R. M. Walker. New York: Cambridge University Press.

Brewer, G. A., and S. C. Selden. 2000. Why elephants gallop: Assessing and predicting organizational performance in federal agencies. Journal of Public Administration Research and Theory 10:685-711.

Brown, T. L., M. Potoski, and D. M. Van Slyke. 2006. Managing public service contracts: Aligning values, institutions, and markets. Public Administration Review 66:323-31.

Cameron, K. S. 1978. Assessing organizational effectiveness in institutions of higher education. Administrative Science Quarterly 23:604-32.

Cameron, K. S. 1981. Domains of organizational effectiveness in colleges and universities. Academy of Management Journal 24:25-47.

1982. The relationship between faculty unionism and organizational effectiveness. Academy of Management Journal 25:6-24.

Campbell, D., and D. Harris. 1993. Flexibility in long-term contractual relationships: The role of co-operation. Journal of Law and Society 20:166-91.

Chun, Y. H., and H. G. Rainey. 2005. Goal ambiguity and organizational performance in the U.S. federal agencies. Journal of Public Administration Research and Theory 15:529-57.

Cohen, J. 1973. Eta-squared and partial eta-squared in fixed factor ANOVA designs. Educational and Psychological Measurement 33:107-12.

Cohen, S. 2001. A strategic framework for devolving responsibility and functions from government to the private sector. Public Administration Review 61:432-40.

Cohen, S. and W. Eimicke. 2008. The responsible contract manager: Protecting the public interest in an outsourced world. Washington, DC: Georgetown University Press.

DeHoog, R. 1990. Competition, negotiation, or cooperation: Three models for service contracting. Administration and Society 22:317-40. 
Donahue, A. N., S. C. Selden, and P. W. Ingraham. 2000. Measuring government management capacity: A comparative analysis of city human resources management systems. Journal of Public Administration Research and Theory 10:381-411.

Ebaugh, H. R., P. Pipes, J. Chafetz, and M. Daniels. 2003. Where's the religion? Distinguishing faith-based from secular social service agencies. Journal for the Scientific Study of Religion 42:411-26.

Eggleston, K., and R. Zeckhauser. 2002. Government contracting for health care. In Marketbased governance, ed. J.D. Donahue and J. S. Nye Jr. Washington, DC: Brookings Institution Press.

Enticott, G., G. A. Boyne, and R. M. Walker. 2009. The use of multiple informants in public administration research: Data aggregation using organizational echelons. Journal of Public Administration Research and Theory 19:229-53.

Forbes, M., and L. E. Lynn. 2005. How does public management affect government performance? Findings from international research. Journal of Public Administration Research and Theory 15:559-84.

Greenwald, R., L. Hedges, and R. Laine. 1996. Interpreting research on school resources and student achievement: A rejoinder to Hanshek. Review of Educational Research 66:4116.

Goerdel, H. 2006. Taking initiative: Proactive management and organizational performance in networked environments. Journal of Public Administration Research and Theory 16:351-67.

Golden, B. R. 1992. Is the past the past—or is it? The use of retrospective accounts as indicators of past strategies. Academy of Management Journal 35:848-60.

Griffiths, W. E., R. C. Hill, and G. G. Judge. 1993. Learning and practicing econometrics. New York: John Wiley and Sons.

Gujarati, D. N. 1993. Basic econometrics. New York: McGraw-Hill.

Hanushek, E.A. 1996. A more complete picture of school resource policies. Review of Educational Research 66:397-409.

Harrington, C., S. Woolhandler, J. Mullan, H. Carrillo, and D. U. Himmelstein. 2001. Does investor ownership of nursing homes compromise the quality of care? American Journal of Public Health 91:1452-5.

Hart, O., A. Shleifer, and R. W. Vishny. 1997. The proper scope of government theory and an application to prisons. The Quarterly Journal of Economics 112:1127-61.

Hatry, H. 2006. Performance measurement: Getting results. Washington, D.C.: Urban Institute Press.

Hou, Y., D. P. Moynihan, and P. W. Ingraham. 2003. Capacity, management, and performance: Exploring the links. The American Review of Public Administration 33:295-315.

Kaplan, R. S., and D. P. Norton. 1992. The balanced scorecard-Measures that drive performance. Harvard Business Review 70:71-9.

Kelly, J. M., and D. Swindell. 2002. A multiple-indicator approach to municipal service evaluation: Correlating performance measurement and citizen satisfaction across jurisdictions. Public Administration Review 62:610-21.

Lambright, K. T. 2009. Agency theory and beyond: Contracted providers' motivations to properly use service monitoring tools. Journal of Public Administration Research and Theory 19:207-27. 
Jencks, C., and M. Phillips, ed. 1998. The black-white test score gap. Washington, DC: The Brookings Institution.

Levy, R. 2001. EU programme management 1977-96: A performance indicators analysis. Public Administration 79:423-44.

Linder, J. C. 2004. Outsourcing for radical change: A bold approach to enterprise transformation. New York: American Management Association.

Macneil, I. 1974. The many futures of contracts. Southern California Law Review 47:691-816.

Macneil, I. R. 1978. Contracts: Adjustment of long-term economic relations under classical, neoclassical, and relational contract law. Northwestern University Law Review 72:854905.

. 1983. Values in contracts: Internal and external. Northwestern University Law Review 78:340-418.

Meier, K. J., and L. J. O’Toole. 2002. Public management and organizational performance: The effect of managerial quality. Journal of Policy Analysis and Management 21:629-43.

Meier, K. J., and L. J., O’Toole. 2003. Public management and educational performance: The impact of managerial networking. Public Administration Review 63:689-99.

Meier, K.J., L. J. O'Toole, G. A. Boyne, and R. M., Walker. 2007. Strategic management and the performance of public organizations: Testing venerable ideas against recent theories. Journal of Public Administration Research and Theory 17:357-77.

Milgrom, P., and J. Roberts. 1992. Economics, organizations, and management. Englewood Cliffs, NJ: Prentice Hall.

Milward, H. B., and K. G. Provan. 2000. Governing the hollow state. Journal of Public Administration Research and Theory 10:359-79.

Morley, J. 2006. For-profit and nonprofit charter schools: An agency costs approach. Yale Law Journal, 115:1782-821.

Moynihan, D., and S. Pandey. 2005. Testing how management matters in an era of government by performance management. Journal of Public Administration Research and Theory 15:421-39.

Moynihan, D. P. 2006. What do we talk about when we talk about performance? Dialogue theory and performance budgeting. Journal of Public Administration Research and Theory 16:151-68.

Moynihan, D. P., and P. W. Ingraham. 2003. Looking for the silver lining: When performancebased accountability systems work. Journal of Public Administration Research and Theory 13:469-90.

O’Toole, L., and K. Meier. 1999. Modeling the impact of public management: Implications of structural context. Journal of Public Administration Research and Theory 9:505-26.

O'Neill, C., C. Harrington, M. Kitchener, and D. Saliba. 2003. Quality of care in nursing homes: An analysis of relationships among profit, quality, and ownership. Medical Care 41:1318-30.

Pitts, D. W. 2005. Diversity, representation, and performance: Evidence about race and ethnicity in public organizations. Journal of Public Administration Research and Theory 15:615-31.

Phillips, L. W. 1981. Assessing measurement error in key informant reports: A methodological note on organizational analysis in marketing. Journal of Marketing Research 18:395415. 
Poister, T. H. 2003. Measuring performance in public and nonprofit organizations. San Francisco: Jossey-Bass.

Provan, K. G., and H. B. Milward. 1995. A preliminary theory of interorganizational network effectiveness: A comparative study of four community mental health systems. Administrative Science Quarterly 40:1-33.

Quinn, R. E., \& J. Rohrbaugh. 1981. A competing values approach to organizational effectiveness. Public Productivity Review 5:122-40. . 1983. A spatial model of effectiveness criteria. Management Science 29:363-77.

Rainey, H. G., and P. Steinbauer. 1999. Galloping elephants: Developing elements of a theory of effective government organizations. Journal of Public Administration Research and Theory 9:1-32.

Rojas, R. R. 2000. A review of models for measuring organizational effectiveness among forprofit and nonprofit organizations. Nonprofit Management and Leadership 11:97-104.

Romzek, B. S., and J. M. Johnston. 2005. State social services contracting: Exploring the determinants of effective contract accountability. Public Administration Review 65:43649.

Sclar, E. D. 2000. You don't always get what you pay for: The economics of privatization. Ithaca, NY: Cornell University Press.

Selden, S. C., and Sowa, J. E. 2004. Testing a multi-dimensional model of organizational performance: Prospects and problems. Journal of Public Administration Research and Theory 14:395-416.

Tsui, A. S. 1990. A multiple-constituency model of effectiveness: An empirical examination at the human resource subunit level. Administrative Science Quarterly 35:458-83.

Van Slyke, D. M. 2007. Agents or stewards: Using theory to understand the governmentnonprofit social service contracting relationship. Journal of Public Administration Research and Theory 17:157-87.

Walker, R. M., and G. A. Boyne. 2006. Public management reform and organizational performance: An empirical assessment of the U.K. Labour government's public service improvement strategy. Journal of Policy Analysis and Management 25:371-93. . 2008. An organizational echelon analysis of the determinants of red tape in public organizations. Public Administration Review 68:1112-27.

Walker, R. M., and G. Enticott. 2004. Using multiple informants in public administration: Revisiting the managerial values and action debate. Journal of Public Administration Research and Theory 14:417-34.

Wu, D. M. 1973. Alternative tests of independence between stochastic regressors and disturbances. Econometrica 41:733-50. 
Table 1. Summary of Hypotheses

\begin{tabular}{|c|c|c|c|c|}
\hline \multirow[b]{2}{*}{ Performance Determinants } & \multicolumn{4}{|c|}{ Performance Measures } \\
\hline & $\begin{array}{l}\text { Number of } \\
\text { Violations }\end{array}$ & $\begin{array}{l}\text { Directors' } \\
\text { Satisfaction }\end{array}$ & $\begin{array}{l}\text { Teachers' } \\
\text { Satisfaction }\end{array}$ & $\begin{array}{c}\text { Parents' } \\
\text { Satisfaction }\end{array}$ \\
\hline \multicolumn{5}{|l|}{ Management Capacity } \\
\hline Internal management practices & Negative & Positive & Positive & Positive \\
\hline Teacher training & No impact & Positive & Positive & Positive \\
\hline Child care center student-teacher ratio & Positive & Negative & Negative & Negative \\
\hline Financial resources & Negative & Positive & Positive & Positive \\
\hline \multicolumn{5}{|l|}{ Organizational Traits } \\
\hline Size & Negative & No impact & Negative & Negative \\
\hline Part of a larger organization & Negative & Negative & Negative & Negative \\
\hline Nonprofit organization & No impact & No impact & Positive & Positive \\
\hline Faith-based organization & No impact & Negative & Negative & Negative \\
\hline Percent of white students & Negative & Positive & Positive & Positive \\
\hline Percent of subsidized families & Positive & Negative & Negative & Negative \\
\hline \multicolumn{5}{|l|}{ Contract Relationship } \\
\hline Completeness & No impact & Negative & Negative & No impact \\
\hline Current relationship strength & No impact & Positive & No impact & No impact \\
\hline Collaborative contract development & No impact & Positive & No impact & No impact \\
\hline Relationship length & No impact & Competing & No impact & No impact \\
\hline
\end{tabular}

Note: Regulatory violations are a negative measure of performance 
Table 2. Descriptive Statistics

\begin{tabular}{|c|c|c|c|c|}
\hline & Variable & Mean & Std. Dev. & $\mathrm{N}$ \\
\hline \multicolumn{5}{|l|}{ Dependent Variables } \\
\hline & Number of violations & 8.298 & 8.213 & 131 \\
\hline & Directors' satisfaction & 4.239 & 0.852 & 163 \\
\hline & Teachers' satisfaction & 3.289 & 0.479 & 104 \\
\hline & Parents' satisfaction & 3.418 & 0.317 & 125 \\
\hline \multicolumn{5}{|l|}{ Explanatory Variables } \\
\hline & Management Capacity & & & \\
\hline & Internal management practices & 29.808 & 31.744 & 163 \\
\hline \multicolumn{5}{|c|}{ Human resources } \\
\hline & Proportion of teachers with a Bachelor's degree & 16.157 & 24.133 & 157 \\
\hline & Proportion of teachers with a Master's degree & 1.681 & 7.501 & 154 \\
\hline & Child care center student-teacher ratio & 9.564 & 2.574 & 163 \\
\hline \multicolumn{5}{|c|}{ Financial resources } \\
\hline & Child care center budget-student ratio( $\$ 1000)$ & 416.414 & 496.829 & 163 \\
\hline & \multicolumn{4}{|l|}{ Organizational Traits } \\
\hline & Number of preschoolers & 32.938 & 18.816 & 163 \\
\hline & Annual budget $(\$ 1000)$ & 14.587 & 10.967 & 163 \\
\hline & Part of a larger organization & 0.436 & 0.497 & 163 \\
\hline & Nonprofit organization & 0.466 & 0.500 & 163 \\
\hline & Faith-based organization & 0.172 & 0.378 & 163 \\
\hline & Percent of white students & 53.036 & 36.632 & 163 \\
\hline & Percent of subsidized students & 59.641 & 39.315 & 159 \\
\hline & \multicolumn{4}{|l|}{ Contract Relationship } \\
\hline & Completeness & 6.399 & 1.648 & 163 \\
\hline & Current relationship strength & 3.667 & 0.832 & 158 \\
\hline & Collaborative contract development & 0.736 & 0.442 & 163 \\
\hline & Relationship length & 3.051 & 1.660 & 163 \\
\hline & \multicolumn{4}{|l|}{ Teacher Related Controls } \\
\hline & Teachers' benefits & 3.263 & 2.060 & 104 \\
\hline & Administrative support for teachers & 8.250 & 1.277 & 104 \\
\hline & Training opportunities for teachers & 97.566 & 12.624 & 163 \\
\hline & \multicolumn{4}{|l|}{ Parent Related Controls } \\
\hline & Parents' age & 28.723 & 5.473 & 125 \\
\hline & Parents' participation in classroom & 3.421 & 5.631 & 125 \\
\hline & Intensity of center use & 4.267 & 0.560 & 125 \\
\hline & Percent of Head Start recipients & 0.052 & 0.072 & 125 \\
\hline & Parents' contribution to education at home & 4.886 & 1.362 & 125 \\
\hline & Parents' education level & 2.947 & 0.707 & 125 \\
\hline & Parents' race & 67.095 & 36.463 & 125 \\
\hline \multicolumn{5}{|l|}{ Control Variables } \\
\hline & Rural area & 0.172 & 0.378 & 163 \\
\hline & wave2 & 0.288 & 0.454 & 163 \\
\hline & wave3 & 0.233 & 0.424 & 163 \\
\hline
\end{tabular}


Table 3. Violation Model (Dependent Variable=Number of Violations)

\begin{tabular}{|c|c|c|c|}
\hline & $\begin{array}{r}\text { Parameter } \\
\text { Estimate }\end{array}$ & $\begin{array}{r}\text { Standard } \\
\text { Error } \\
\end{array}$ & P-value \\
\hline \multicolumn{4}{|l|}{ Management Capacity } \\
\hline Internal management practices & -0.016 & 0.023 & 0.491 \\
\hline \multicolumn{4}{|l|}{ Human resources } \\
\hline Proportion of teachers with a Bachelor's degree & -0.049 & 0.029 & 0.095 \\
\hline Proportion of teachers with a Master's degree & -0.003 & 0.093 & 0.976 \\
\hline Child care center student-teacher ratio & 0.738 & $0.312 *$ & 0.020 \\
\hline \multicolumn{4}{|l|}{ Finance resources } \\
\hline Child care center budget-student ratio $(\$ 1000)$ & 0.254 & $0.128 *$ & 0.049 \\
\hline \multicolumn{4}{|l|}{ Organizational Traits } \\
\hline Number of preschoolers & 0.059 & 0.080 & 0.465 \\
\hline Annual budget(\$1000) & -0.005 & $0.003 *$ & 0.042 \\
\hline Part of a larger organization & -2.016 & 2.050 & 0.328 \\
\hline Nonprofit organization & -2.655 & 2.393 & 0.270 \\
\hline Faith-based organization & 3.393 & 2.559 & 0.175 \\
\hline Percent of white students & 0.052 & $0.025 *$ & 0.044 \\
\hline Percent of subsidized students & -0.006 & 0.022 & 0.777 \\
\hline \multicolumn{4}{|l|}{ Contract Relationship } \\
\hline Completeness & 0.362 & 0.534 & 0.500 \\
\hline Current relationship strength & 1.110 & 0.979 & 0.260 \\
\hline Collaborative contract development & 0.890 & 1.641 & 0.589 \\
\hline Relationship length & 0.735 & 0.569 & 0.200 \\
\hline \multicolumn{4}{|l|}{ Controls } \\
\hline Rural area & -4.725 & 2.726 & 0.086 \\
\hline wave2 & 1.490 & 1.764 & 0.400 \\
\hline wave3 & 2.716 & 2.344 & 0.249 \\
\hline Intercept & -11.825 & 8.229 & 0.154 \\
\hline R-square & \multicolumn{2}{|c|}{0.255} & \\
\hline Adjusted R-square & \multicolumn{2}{|c|}{0.110} & \\
\hline $\mathbf{N}$ & \multicolumn{2}{|c|}{118} & \\
\hline
\end{tabular}

${ }^{*} \mathrm{p}<0.05,{ }^{* *} \mathrm{p}<0.01,{ }^{* * *} \mathrm{p}<0.001$ 
Table 4. Directors' Model (Dependent Variable = Directors' Satisfaction)

\begin{tabular}{|c|c|c|c|c|}
\hline & $\begin{array}{r}\text { Parameter } \\
\text { Estimate } \\
\end{array}$ & $\begin{array}{r}\text { Standard } \\
\text { Error } \\
\end{array}$ & & P-value \\
\hline \multicolumn{5}{|l|}{ Management Capacity } \\
\hline Internal management practices & -0.001 & 0.005 & & 0.924 \\
\hline \multicolumn{5}{|l|}{ Human resources } \\
\hline Proportion of teachers with a Bachelor's degree & 0.030 & 0.009 & $* * *$ & $<.001$ \\
\hline Proportion of teachers with a Master's degree & 0.041 & 0.029 & & 0.153 \\
\hline Child care center student-teacher ratio & -0.103 & 0.077 & & 0.183 \\
\hline \multicolumn{5}{|l|}{ Finance resources } \\
\hline Child care center budget-student ratio(\$1000) & -0.074 & 0.034 & * & 0.030 \\
\hline \multicolumn{5}{|l|}{ Organizational Traits } \\
\hline Number of preschoolers & -0.030 & 0.019 & & 0.100 \\
\hline Annual budget( $\$ 1000)$ & 0.003 & 0.002 & & 0.060 \\
\hline Part of a larger organization & 0.810 & 0.477 & & 0.089 \\
\hline Nonprofit organization & 0.335 & 0.566 & & 0.554 \\
\hline Faith-based organization & -0.211 & 0.559 & & 0.706 \\
\hline Percent of white students & 0.012 & 0.006 & $*$ & 0.046 \\
\hline Percent of subsidized students & 0.001 & 0.005 & & 0.905 \\
\hline \multicolumn{5}{|l|}{ Contract Relationship } \\
\hline Completeness & -0.371 & 0.129 & $* *$ & 0.004 \\
\hline Current relationship strength & 0.778 & 0.245 & $* *$ & 0.002 \\
\hline Collaborative contract development & -0.470 & 0.414 & & 0.256 \\
\hline Relationship length & -0.274 & 0.146 & & 0.0610 .045 \\
\hline \multicolumn{5}{|l|}{ Controls } \\
\hline Rural area & -.0 .617 & 0.592 & & 0.297 \\
\hline wave2 & 0.890 & 0.432 & $*$ & 0.039 \\
\hline wave3 & 0.854 & 0.554 & & 0.123 \\
\hline Intercept5 & 0.208 & 1.740 & & 0.905 \\
\hline Intercept4 & 2.613 & 1.758 & & 0.137 \\
\hline Intercept3 & 4.232 & 1.808 & $*$ & 0.019 \\
\hline Intercept2 & 5.401 & 1.910 & $* *$ & 0.005 \\
\hline LR chi-square & \multicolumn{2}{|c|}{44.64} & & \\
\hline Pseudo R-square & \multicolumn{2}{|c|}{0.136145} & & \\
\hline $\mathbf{N}$ & \multicolumn{2}{|c|}{146} & & \\
\hline
\end{tabular}

${ }^{*} \mathrm{p}<0.05,{ }^{* *} \mathrm{p}<0.01,{ }^{* * *} \mathrm{p}<0.001$ 
Table 5. Teachers' Model (Dependent Variable=Teachers' Satisfaction)

\begin{tabular}{|c|c|c|c|}
\hline & $\begin{array}{r}\text { Parameter } \\
\text { Estimate } \\
\end{array}$ & $\begin{array}{r}\text { Standard } \\
\text { Error } \\
\end{array}$ & P-value \\
\hline \multicolumn{4}{|l|}{ Management Capacity } \\
\hline Internal management practices & 0.001 & 0.001 & 0.180 \\
\hline \multicolumn{4}{|l|}{ Human resources } \\
\hline Proportion of teachers with a Bachelor's degree & 0.002 & 0.001 & 0.205 \\
\hline Proportion of teachers with a Master's degree & 0.009 & $0.004^{*}$ & 0.017 \\
\hline Child care center student-teacher ratio & 0.028 & 0.015 & 0.067 \\
\hline \multicolumn{4}{|l|}{ Finance resources } \\
\hline Child care center budget-student ratio(\$1000) & 0.015 & 0.008 & 0.061 \\
\hline \multicolumn{4}{|l|}{ Organizational Traits } \\
\hline Number of preschoolers & 0.002 & 0.003 & 0.4620 .006 \\
\hline Annual budget(\$1000) & -0.000 & 0.000 & 0.170 \\
\hline Part of a larger organization & -0.313 & $0.110^{* *}$ & 0.0060 .151 \\
\hline Nonprofit organization & 0.206 & 0.128 & 0.114 \\
\hline Faith-based organization & -0.111 & 0.100 & 0.269 \\
\hline Percent of white students & 0.002 & 0.001 & 0.170 \\
\hline Percent of subsidized students & $-<.0001$ & 0.001 & 0.921 \\
\hline \multicolumn{4}{|l|}{ Contract Relationship } \\
\hline Completeness & -0.038 & 0.021 & 0.080 \\
\hline Current relationship strength & 0.085 & 0.047 & 0.076 \\
\hline Collaborative contract development & -0.245 & $0.078 * *$ & 0.002 \\
\hline Relationship length & 0.119 & $0.033^{* *}$ & 0.001 \\
\hline \multicolumn{4}{|l|}{ Teacher Related Controls } \\
\hline Teachers' benefits & 0.052 & $0.023^{*}$ & 0.028 \\
\hline Administrative support for teachers & 0.240 & $0.027 * * *$ & $<.0001$ \\
\hline Training opportunities for teachers & -0.001 & 0.003 & 0.851 \\
\hline \multicolumn{4}{|l|}{ Other Controls } \\
\hline Rural area & 0.141 & 0.098 & 0.156 \\
\hline wave2 & -0.104 & 0.082 & 0.208 \\
\hline wave3 & -0.160 & 0.113 & 0.161 \\
\hline Intercept & 0.399 & 0.456 & 0.384 \\
\hline R-square & 0.747 & & \\
\hline Adjusted R-square & 0.668 & & \\
\hline $\mathbf{N}$ & 94 & & \\
\hline
\end{tabular}


Table 6. Parents' Models (Dependent Variable $=$ Parents' Satisfaction)

\begin{tabular}{|c|c|c|c|c|c|c|c|}
\hline & $\begin{array}{r}\text { Parameter } \\
\text { Estimate }\end{array}$ & $\begin{array}{r}\text { Standar } \\
\text { Erro } \\
\end{array}$ & & P-value & $\begin{array}{r}\text { Parameter } \\
\text { Estimate } \\
\end{array}$ & $\begin{array}{r}\text { andard } \\
\text { Error }\end{array}$ & P-value \\
\hline \multicolumn{8}{|l|}{ Management Capacity } \\
\hline Internal management practices & 0.002 & 0.001 & $*$ & 0.012 & 0.001 & 0.001 & 0.296 \\
\hline \multicolumn{8}{|l|}{ Human resources } \\
\hline Proportion of teachers with a Bachelor's degree & 0.001 & 0.001 & & 0.355 & 0.0004 & 0.001 & 0.736 \\
\hline Proportion of teachers with a Master's degree & $-<.0001$ & 0.003 & & 0.871 & -0.005 & 0.003 & 0.078 \\
\hline Child care center student-teacher ratio & -0.021 & 0.011 & & 0.062 & -0.031 & $0.013^{*}$ & 0.027 \\
\hline \multicolumn{8}{|l|}{ Finance resources } \\
\hline Child care center budget-student ratio( $\$ 1000)$ & 0.000 & 0.004 & & 0.927 & -0.004 & 0.007 & 0.546 \\
\hline \multicolumn{8}{|l|}{ Organizational Traits } \\
\hline Number of preschoolers & $0 . .000$ & 0.002 & & 0.952 & 0.001 & 0.003 & 0.770 \\
\hline Annual budget(\$1000) & $<.0001$ & $<.0001$ & & 0.757 & $<.0001$ & 0.000 & 0.513 \\
\hline Part of a larger organization & -0.283 & 0.082 & $* * *$ & 0.001 & -0.354 & $0.110 * *$ & 0.003 \\
\hline Nonprofit organization & 0.150 & 0.096 & & 0.123 & 0.176 & 0.172 & 0.313 \\
\hline Faith-based organization & 0.048 & 0.087 & & 0.5821 & 0.075 & 0.152 & 0.625 \\
\hline Percent of white students & -0.006 & 0.002 & $* * *$ & 0.0003 & -0.005 & $0.002 * *$ & 0.008 \\
\hline Percent of subsidized students & -0.002 & 0.001 & $*$ & 0.014 & -0.001 & 0.001 & 0.138 \\
\hline \multicolumn{8}{|l|}{ Contract Relationship } \\
\hline Completeness & -0.024 & 0.018 & & 0.181 & -0.003 & 0.018 & 0.845 \\
\hline Current relationship strength & 0.113 & 0.036 & $* *$ & 0.002 & 0.063 & 0.038 & 0.103 \\
\hline Collaborative contract development & -0.123 & 0.063 & & 0.053 & -0.016 & 0.064 & 0.803 \\
\hline Relationship length & 0.067 & 0.022 & $* *$ & 0.003 & 0.022 & 0.037 & 0.562 \\
\hline \multicolumn{8}{|l|}{ Parent Related Controls } \\
\hline Parents' age & -0.000 & 0.007 & & 0.959 & 0.026 & $0.010 * *$ & 0.008 \\
\hline Parents' participation in classroom & 0.008 & 0.006 & & 0.142 & -0.001 & 0.009 & 0.892 \\
\hline Intensity of service use & 0.215 & 0.057 & $* * *$ & 0.000 & 0.365 & $0.095 * * *$ & 0.000 \\
\hline Percent of Head Start recipients & -0.221 & 0.396 & & 0.577 & 0.441 & 0.509 & 0.392 \\
\hline Parents' contribution to education & 0.004 & 0.024 & & 0.850 & 0.022 & 0.025 & 0.384 \\
\hline Parents' education level & 0.070 & 0.050 & & 0.167 & -0.074 & 0.061 & 0.236 \\
\hline Parents' race & 0.007 & 0.002 & $* * *$ & $<.0001$ & 0.004 & 0.002 & 0.117 \\
\hline \multicolumn{8}{|l|}{ Other Quality Measures } \\
\hline Number of violations & & & & & -0.005 & 0.004 & 0.268 \\
\hline Directors' satisfaction & & & & & 0.113 & 0.057 & 0.055 \\
\hline Teachers' satisfaction & & & & & 0.401 & $0.078 * * *$ & $<.0001$ \\
\hline \multicolumn{8}{|l|}{ Other Controls } \\
\hline Rural & 0173 & 0.084 & $*$ & 0.042 & 0.116 & 0.102 & 0.262 \\
\hline wave2 & -0.039 & 0.060 & & 0.516 & 0.042 & 0.080 & 0.601 \\
\hline wave3 & -0.081 & 0.081 & & 0.317 & 0.0350 & 11104 & 0.753 \\
\hline Intercept & 2.0931 .746 & 0.407 & $* * *$ & $<.0001$ & -0.428 & 0.649 & 0.513 \\
\hline R-square & 0.597 & & & & 0.822 & & \\
\hline Adjusted R-square & 0.474 & & & & 0.696 & & \\
\hline $\mathbf{N}$ & 112 & & & & 71 & & \\
\hline
\end{tabular}


${ }^{*} \mathrm{p}<0.05,{ }^{* *} \mathrm{p}<0.01,{ }^{* * *} \mathrm{p}<0.001$ 


\begin{tabular}{|c|c|c|c|c|}
\hline \multirow[b]{2}{*}{ Variables } & \multicolumn{4}{|c|}{ Models } \\
\hline & $\begin{array}{c}\text { Violation } \\
\text { Model }\end{array}$ & $\begin{array}{c}\text { Directors' } \\
\text { Model }\end{array}$ & $\begin{array}{c}\text { Teachers' } \\
\text { Model }\end{array}$ & $\begin{array}{c}\text { Parents' Model } \\
\text { (without } \\
\text { quality } \\
\text { measures from } \\
\text { other models) }\end{array}$ \\
\hline \multicolumn{5}{|l|}{ Management Capacity } \\
\hline Internal management practices & & & & $\begin{array}{c}\text { Positive } \\
(.072)\end{array}$ \\
\hline Proportion of teachers with a Bachelor's degree & & $\begin{array}{c}\text { Positive } \\
(.076)\end{array}$ & & \\
\hline Proportion of teachers with a Master's degree & & & $\begin{array}{c}\text { Positive } \\
(.078)\end{array}$ & \\
\hline Child care center student-teacher ratio & $\begin{array}{c}\text { Positive } \\
(.054)\end{array}$ & & & \\
\hline Child care center budget-student ratio(\$1000) & $\begin{array}{c}\text { Positive } \\
(.039)\end{array}$ & $\begin{array}{c}\text { Negative } \\
\text { (.018) }\end{array}$ & & \\
\hline \multicolumn{5}{|l|}{ Organizational Traits } \\
\hline Number of preschoolers & & & & \\
\hline Annual budget $(\$ 1000)$ & $\begin{array}{c}\text { Negative } \\
\text { (.041) }\end{array}$ & & & \\
\hline Part of a larger organization & & & $\begin{array}{c}\text { Negative } \\
\text { (.103) }\end{array}$ & $\begin{array}{c}\text { Negative } \\
\text { (.124) }\end{array}$ \\
\hline Nonprofit organization & & & & \\
\hline Faith-based organization & & & & \\
\hline Percent of white students & $\begin{array}{c}\text { Positive } \\
\text { (.041) }\end{array}$ & $\begin{array}{c}\text { Positive } \\
(.012)\end{array}$ & & $\begin{array}{c}\text { Negative } \\
(.144)\end{array}$ \\
\hline Percent of subsidized students & & & & $\begin{array}{c}\text { Negative } \\
\text { (.068.) }\end{array}$ \\
\hline \multicolumn{5}{|l|}{ Contract Relationship } \\
\hline Completeness & & $\begin{array}{c}\text { Negative } \\
\text { (.061) }\end{array}$ & & \\
\hline Current relationship strength & & $\begin{array}{l}\text { Positive } \\
\text { (.039) }\end{array}$ & & $\begin{array}{c}\text { Positive } \\
\text { (.106) }\end{array}$ \\
\hline Collaborative contract development & & & $\begin{array}{c}\text { Negative } \\
(.122)\end{array}$ & \\
\hline Relationship length & & & $\begin{array}{c}\text { Positive } \\
(.157)\end{array}$ & $\begin{array}{c}\text { Positive } \\
(.098)\end{array}$ \\
\hline \multicolumn{5}{|l|}{ Teacher Related Controls } \\
\hline Teachers' benefits & & & $\begin{array}{c}\text { Positive } \\
(.066)\end{array}$ & \\
\hline Administrative support for teachers & & & $\begin{array}{c}\text { Positive } \\
\text { (.536) }\end{array}$ & \\
\hline Training opportunities for teachers & & & & \\
\hline \multicolumn{5}{|l|}{ Parent Related Controls } \\
\hline Parents’age & & & & \\
\hline \multicolumn{5}{|l|}{ Parents' participation in classroom } \\
\hline Intensity of service use & & & & $\begin{array}{c}\text { Positive } \\
\text { (.143) }\end{array}$ \\
\hline Percent of Head Start recipients & & & & \\
\hline Parents' contribution to education & & & & \\
\hline Parents' education level & & & & \\
\hline Parents' race & & & & $\begin{array}{c}\text { Positive } \\
(.166)\end{array}$ \\
\hline
\end{tabular}




\begin{tabular}{|c|c|c|c|c|c|}
\hline \multirow[b]{2}{*}{ Variables } & & \multicolumn{4}{|c|}{ Models } \\
\hline & & $\begin{array}{c}\text { Violation } \\
\text { Model }\end{array}$ & $\begin{array}{c}\text { Directors' } \\
\text { Model } \\
\end{array}$ & $\begin{array}{c}\text { Teachers' } \\
\text { Model }\end{array}$ & $\begin{array}{c}\text { Parents' Model } \\
\text { (without } \\
\text { quality } \\
\text { measures from } \\
\text { other models) }\end{array}$ \\
\hline \multicolumn{6}{|c|}{ Other Controls } \\
\hline & Rural & & & & $\begin{array}{c}\text { Positive } \\
(.048)\end{array}$ \\
\hline
\end{tabular}

Note: Effect sizes (partial eta ${ }^{2}$ ) were estimated by using a Stata program, regeffectsize. Partial eta ${ }^{2}$ is the proportion of variance in the dependent variable attributable to the corresponding explanatory variable (Cohen, 1973). In the analysis section, the directors' model was estimated using ordered logit. However, effect sizes reported for the directors' model in this table were estimated using OLS. 


\section{Appendix 1. Dependent and Independent Variables}

\section{DEPENDENT VARIABLES}

Number of violations: Number of violations documented during state licensing inspections

Director's satisfaction: How satisfied are you with the overall quality of your center? ( $5=$ Very satisfied

4=Somewhat satisfied 3=Neither satisfied nor dissatisfied $2=$ Not very satisfied $1=$ Not satisfied at all)

Teachers assessment of quality: How would you rate the overall quality of this child care center? $(4=$ Excellent $3=$ Good 2= Fair 1= Poor)

Parental quality assessment: How would you rate the overall quality of your child's care at this center? (4= Excellent 3= Good 2= Fair 1= Poor).

\section{MANAGEMENT CAPACITY}

Internal management practices (Cronbach alpha $=0.777)$ : Sum of seven dichotomous survey items. Please indicate the average number of times someone in an administrative role at your center, such as an education coordinator, administrator, or senior teacher, engages in the following activities during a typical month: (1) observes teachers in the classroom to assess their practice; (2) meets with teachers to provide feedback regarding their teaching practices in the classroom; (3) meets with teachers to discuss how to link the curriculum to children's developmental needs; (4) discusses with teachers strategies to ensure teaching practice is developmentally appropriate; (5) discusses with teachers strategies to ensure a literacy-rich curriculum; (6) reviews teachers' teaching; and (7) reviews program data to see how the center is doing compared to specific goals or objectives. Proportion of teachers with a Bachelor's degree: Sum of number of teachers with a Bachelor's degree in early childhood or another field divided by the total number of teachers currently working at the center.

Proportion of teachers with a Master's degree: Sum of number of teachers with a Master's degree or higher in early childhood or another field divided by the total number of teachers currently working at the center.

Child care center student-teacher ratio: Ratio of preschoolers to teachers or teaching aides at the center Child care center budget-student ratio: Ratio of the child care center's budget (unit= $\$ 1000$ ) to the number of preschoolers served by the center

\section{ORGANIZATIONAL TRAITS}

Contractor part of a larger organization: Coded as 1 for centers part of a larger agency or umbrella organization Contractor's organizational size: Average daily enrollment of preschoolers at the child care center (numeric)

Contractor's budget: Child care center's current total annual operating budget (unit $=\$ 1000$ )

Nonprofit contractor: Coded as 1 for nonprofit child care centers

Faith-based contractor: Coded as 1 for faith-based organizations

Contractor in the rural area: Survey item "urbanicity" (1=Urban 2= Suburban 3=Small Town 4=Rural ) was coded as 1 for small towns and rural areas and 0 for other responses.

Percent white: Percent of white preschoolers at the center Percent of subsidized students: Percent of students receiving subsidies at the center CONTRACT RELATIONSHIP

Completeness: Sum of the following survey items measured as dichotomous nominal variables: (1) currently do you have a written legal agreement or a contract with Head Start?; (2) do you regularly update the document?; (3) does this agreement specify the maximum number of children who can receive Head Start enhanced services at your center?; (4) in your partnership with Head Start, do you have a written document that describes roles and responsibilities of Head Start and of people at your center in providing services?; (5) do you have any documents that describe the partnership's goals and specific actions that the partnership plans to take to achieve the goals?; (6) in your partnership, do you have any written documents that state what your program needs to do to meet Head Start Program Performance Standards?; (7) do you have documents describing procedures for communicating with your Head Start partner?; and (8) do you have a well-defined process for recruiting and enrolling children into your center for Head Start enhanced services?

Current relationship strength: Mean of variables "shared procedures," "goal agreement," "communication quality," and "cooperation in contract implementation"

Shared procedures (Cronbach alpha $=0.906$ ): Sum of the eight survey items measured on a 5 point Likert scale. The partnership between my child care center and Head Start has: (1) a process for ensuring child care staff have a 
good understanding of Head Start, (2) a process to ensure staff understand Head Start regulations, (3) procedures for resolving conflicts or differences across your programs, (4) ensured that child care staff are prepared for their new responsibilities, (5) ensured that all staff are involved in all phases of partnerships, (6) procedures to keep children in the program if their parents lose eligibility for child care subsidy, (7) procedures to keep children in the program if their parents lose eligibility for Head Start services, and (8) procedures to manage finances as part of the partnership. Goal agreement (Cronbach alpha=0.875): Sum of four survey items measured on a 5 point Likert scale: (1) the partnership between my child care center and Head Start has a shared partnership philosophy and vision; (2) the partnership between my child care center and Head Start has agreement about the curriculum/educational approach; (3) the partnership between my child care center and Head Start has agreements or plans that help guide the partnership work; and (4) my center and HS have similar goals for our work together.

Communication quality (Cronbach alpha=0.792): Sum of three survey items measured on a 5 point Likert scale: (1) the partnership between my child care center and Head Start has good communication within and across your organizations; (2) I feel my voice is heard in the Partnership; and (3) I feel I can pick up the phone and call the HS program.

Cooperation in contract implementation (Cronbach alpha=0.827): Sum of five survey items measured on a 5 point Likert scale: (1) individuals involved in the partnership between my child care center and Head Start demonstrate mutual respect for one another; (2) I feel my program is a full partner with the HS program; (3) I feel the HS program respects my Program; (4) I feel HS does not really view my center as a partner; and (5) how would you characterize your partnership with Head Start on a scale of 1 to 5 , where $1=$ just forming and 5=fully established?

Collaborative contract development: Coded as 1 when the contract was developed with input from the HS program and child care center

Relationship length: Number of years that the center has engaged in the partnership

\section{TEACHER RELATED VARIABLES}

Benefits for teachers: First, we coded each of the following benefits that an individual teacher indicated receiving as a 1: (1) paid vacation, (2) paid sick leave, (3) paid maternity leave, (4) paid family leave, (5) paid health insurance, (6) paid dental insurance, (7) tuition reimbursement, (8) retirement plan, (9) release time for training, and (10) other benefits. Next, we calculated the sum of the positive answers for each teacher respondent. Third, we aggregated the summed responses by center and divided it by the number of respondents per center.

Administrative support for teachers: First, we summed the positive responses to the following statements by each teacher respondent regarding whether they: (1) have enough time to do all that is required, (2) have clearly defined job responsibilities, (3) have a high enough salary for job demands, (4) get support from other staff, (5) get support from their supervisor, (6) get support and communication from management, (7) get enough funds for supplies and activities, (8) have opportunities to give input to management for changes, (9) have clear goals and objectives for teaching, (10) have a staff handbook at the center, (11) have a center director not afraid of taking risks, and (12) have a collective bargaining agreement at the center. Second, we aggregated the summed responses by center and divided it by the number of respondents per center.

Training opportunities for teachers: Percent of center's preschool teachers who receive training annually PARENT RELATED VARIABLES

Parents' age: Mean age of parents

Parents' participation in classroom: Mean of the frequencies that parents volunteer in the classroom (times per year)

Intensity of service use: Mean of average days per week that children attend the center

$\%$ of Head Start recipients: Percentage of parents who receive support from Head Start

Parents' contribution to education at home: Mean number of times books are read to children at home per week Parents' education level: Mean education level of parents ( $1=$ no diploma $2=$ high school diploma/GED $3=$ trade license or certificate $4=$ associates degree $6=$ graduate degree)

Parents' race: White parents as a percent of all parents participating in the survey for each center 